\title{
AMRL-TR-67-43
}

\section{THE POTENTIAL HAZARD OF STAPHYLOCOCCI AND MICROCOCCI TO HUMAN SUBJECTS IN A LIFE SUPPORT SYSTEMS EVALUATOR WITH ELEVATED CABIN TEMPERATURE}

\section{LEONARD P. LOTTER \\ BONNES S. HORSTMAN}

DEPARTMENT OF RESEARCH, MIAM VALLEY HOSPTTAL

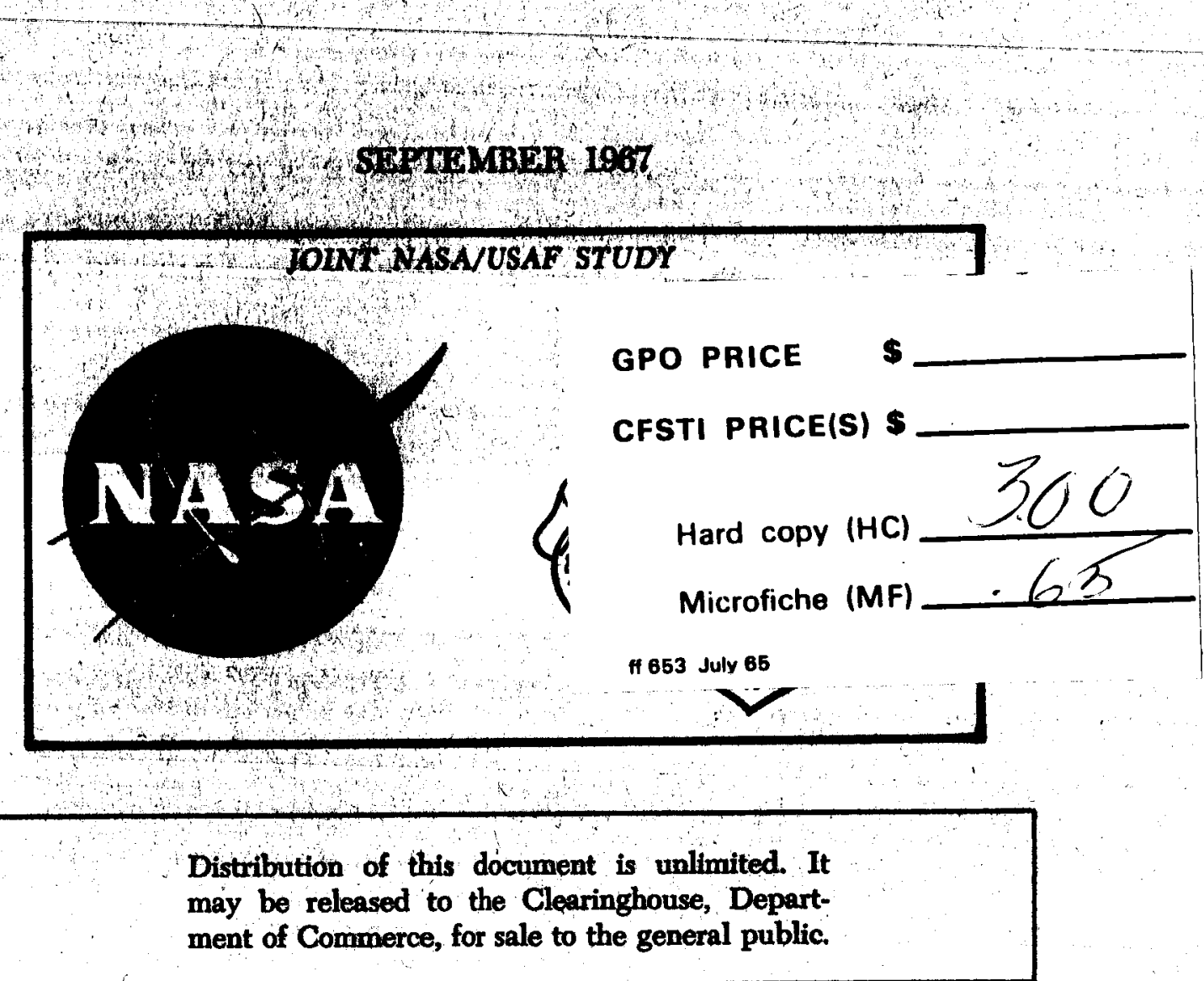

AEROSPACE MEDICAL RESEARCH LABORATORIES AEROSPACE MEDICAL DIVISION

AIR FORCE SYSTEMS COMMAND

WRIGHT-PATTERSON AIR FORCE BASE, OHIO 


\section{NOTCES}

When US Government drawings, specifications, or other data are used for any purpose other than a definitely related Government procurement operation, the Government thereby incurs no responsibility nor any obligation whatsoever, and the fact that the Government may have formulated, furnished, or in any way supplied the said drawings, specifications, or other data, is not to be regarded by implication or otherwise, as in any manner licensing the holder or any other person or corporation, or conveying any rights or permission to manufacture, use, or sell any patented invention that may in any way be related thereto.

Federal Government agencies and their contractors registered with Defense Documentation Center (DDC) should direct requests for copies of this report to:

DDC

Cameron Station

Alexandria, Virginia 22814

Non-DDC users may purchase copies of this report from:

Chief, Storage and Dissemination Sectlon

Clearinghouse for Federal Solentific \& Technical Information (CFST)

Sills Butlding

6285 Port Royal Road

Springfield, Virgtnia 22151

Organizations and individuals receiving reports via the Aerospace Medical Research Laboratories' automatic mailing lists should submit the addressograph plate stamp on the report envelope or refer to the code number when corresponding about change of address or cancellation.

Do not return this copy. Retain or destroy.

The voluntary informed consent of the subjects used in this research was obtained as required by Air Force Regulation 169-8.

600 - January $1967-\operatorname{Co455}-18-365$ 


\title{
THE POTENTIAL HAZARD OF STAPHYLOCOCCI AND MICROCOCCI TO HUMAN SUBJECTS IN A LIFE SUPPORT SYSTEMS EVALUATOR WITH ELEVATED CABIN TEMPERATURE
}

\author{
LEONARD P. LOTTER
}

BONNIE S. HORSTMAN

Distribution of this document is unlimited. It may be released to the Clearinghouse, Department of Commerce, for sale to the general public. 
This research was initiated by the Aerospace Medical Research Laboratories, Wright-Patterson Air Force Base, Ohio, and was accomplished by the Department of Research of the Miami Valley Hospital, Dayton, Ohio, and the Biotechnology Branch, Life Support Division, Biomedical Laboratory, Aerospace Medical Research Laboratories. This effort was supported jointly by the USAF under Project No. 7164, "Biomedical Criteria for Aerospace Flight," Task No. 716405 , "Aerospace Nutrition," and NASA Manned Spacecraft Center, Houston, Texas, under Defense Purchase Request R-85, "The Protein, Water, and Energy Requirements of Man Under Simulated Aerospace Conditions." This contract was initiated by lst Lt John E. Vanderveen, monitored by lst Lt Keith J. Smith, and completed by Alton E. Prince, PhD, for the USAF. Technical contract monitor for NASA was Paul A. Lachance, PhD. The research effort of the Department of Research of the Miami Valley Hospital, was accomplished under Contract AF 33 (657)- 11716. Bernard J. Katchman, PhD, and George M. Homer, PhD, were technical contract administrators, and Robert E. Zipf, MD, Director of Research, had overall contractual responsibility.

The authors wish to acknowledge the technical advice and recommendations of Edward O. Hill, PhD, Assistant Professor of Microbiology and Surgery, and Director, Research Surgical Bacteriology Laboratories, College of Medicine, University of Cincinnati. The statistical analysis of the data was carried out by Mr. Virgil Rehg, Research Associate, Ohio State University. The authors also acknowledge the invaluable assistance of Sheldon $\mathrm{A}$. London, $\mathrm{PhD}, \mathrm{Mr}$. Arselus West, and Mr. Dennis Sulick of AMRL, and Mrs. Corine Gary of the Department of Research.

This report has been reviewed and is approved.

WAYNE H. MCCANDLESS

Technical Director

Biomedical Laboratory

Aerospace Medical Research Laboratories 


\begin{abstract}
Four human male subjects participated in a 6-week simulated aerospace study and were confined under controlled metabolic conditions. During this time 28 consecutive days were spent in a Life Support Systems Evaluator. The subjects ate a diet composed of fresh foods while exposed to simulated aerospace stress of confinement, wearing an unpressurized MA-10 pressure suit, increased environmental temperature, experimental diet, and minimal personal hygienic conditions. Body and environmental areas were sampled and catalase-positive, gram-positive cocci isolated were tested for production of coagulase, deoxyribonuclease, hemolysin, gelatinase, and utilization of mannitol. The results showed no significant differences in frequency of occurrence of biochemical types among subjects and among environmental areas during the chamber period. There were significant differences in the frequency of occurrence of biochemical types on nose, throat, gingiva, axilla, groin, glans penis, anus, and toe. There was no buildup of biochemical types with time in any test condition. Though 3 phage types, 29, 6/7/53/83a, and 6, were recovered initially from 2 subjects, only one subject had transmitted astaphylococcus to other subjects and the environment. Despite the fact that cultures tested by the coagulase plate method were shown to be false positive when tested by the coagulase tube method, in either case the frequency of occurrence of biochemical types did not differ significantly. The same fact was observed when the deoxyribonuclease marker was used to indicate the potentially pathogenic type. The subjects remained healthy without any decrease in resistance to infection throughout all the test conditions. Those body areas most likely to harbor potentially pathogenic staphylococci are nose, groin, glans penis, and anus. In the concurrent metabolic studies the physiological, biochemical and nutritional parameters investigated were all in the normal range of clinical values. Confinement under simulated aerospace conditions for at least 28 consecutive days and conditions of minimal personal hygiene show that no unique set of circumstances are operable that would require the establishment of special biomedical criteria.
\end{abstract}




\section{TABLE OF CONTENTS}

Section No.

Page

I

INTRODUCTION

1

II EXPERIMENTAL METHODS AND PROCEDURES

2

III

RESULTS

8

IV

DISCUSSION

10

REFERENCES

23 


\section{LIST OF TABLES}

Table No.

Page

$1 \quad$ Experimental Design

II Daily Activity Schedule

III Recovery of Biochemical Types from Selected Environmental Areas

IV Recovery of Biochemical Types from Body Areas "A" of Test Subjects

V Recovery of Biochemical Types from Body Areas "B" of Test Subjects

VI Summary of Statistical Analysis of Biochemical Types from Selected Body Areas of Test Subjects and the Environment.

VII Summary of Statistical Analysis of Biochemical Types

"C" Recovered from Selected Body Areas of Test

Subjects and the Environment

VIII Frequency of Biochemical Types Recovered from

Significant Body Areas

IX Recovery of Biochemical Types from Feces of Test

Subjects

\section{LIST OF FIGURES}

Figure No.

1 Relationship of Sampling Day to Isolation of Phage Types from Body Areas of Test Subjects. 


\section{SECTION I}

\section{INTRODUCTION}

Biomedical criteria required to establish the necessary personal hygiene and sanitation procedures for long term flight in space are not available. Of considerable import would be the buildup of microbial populations and the development of deleterious effects on personnel as a consequence of stress induced conditions of long term space flight derived from a variety of parameters.

Several stressful factors have increased occurrence of staphylococcal pathogenicity in man an animals. Starvation, vitamin deficiencies, and protein deficient diets are examples of nutritional stresses that have predisposed man and animals, to staphylococcal infection (1-4). Mice fed a protein deficient diet $(5 \%$ casein) succumbed to infection by Staphylococcus aureus while those on $20 \%$ casein did not (3). The same authors (4) reported that coagulase-negative staphylococci readily infected mice fed another protein deficient diet (corn or glutenlysine) in contrast to the casein enriched diet. These data suggest that maintenance of nutritional balances are important in the resistance of man and animals to microbial infection.

Other stresses such as burns (5), traumatic shock (6), fatigue (7), extensive body irradiation (8), hyposecretion and hypersecretion of hormones (9), and diabetes mellitus, tuberculosis, and kidney damage $(7,10,11)$ have been shown to reduce resistance to infection. Although any of these factors might lower the resistance of astronauts to microbial infection during prolonged space travel, those pertaining to the nutritional status are probably more germane to the problem of space travel stress.

Micrococci, especially S. aureus, have been reported as predominant colonizers on human skin and body surfaces and rank foremost among the potential pathogens (12). Various products or properties of $S$. aureus have been associated with virulence; for example, the production of coagutase, alpha-toxin and hemolysins, leukocidin, lipase, deoxyribonuclease, phosphatase, hyaluronidase, and other enzymes, and the ability to resist phagocytosis (13). Of these properties, coagulase activity has been regarded as the main determinant of staphylococcal pathogenicity (14-17).

Phage typing represents an ancillary approach in identifying potentially pathogenic staphylococci. Blair (18) claimed that only coagulase-positive staphylococci are phage typable, al though $20 \%$ to $30 \%$ of these are not lysed by typing phages . Lysogeny which confers specific prophage immunity may be responsible for insensitivity of staphylococci to these phages (19). Most nosocomial strains of staphylococci are phage sensitive and resistant to one or more antibiotics (18). 
The purpose of this study was to determine the distribution of staphylococci indigenous to humans and their environment in a controlled ecological system and to ascertain if the associated biochemical markers provide reliable criteria of pathogenicity. A buildup of these organisms or their transfer among humans and their environment, or even among specific body regions, may pose a threat to the health of humans during long term space flight. Lotter, Horstman, and Rack observed that healthy human male subjects confined in a simulated aerospace environment did not become more susceptible to staphylococcal infection $(20,21)$. During confinement the subjects ate diets of fresh foods (22), precooked freeze dehydrated foods (23), or liquid foods (24). In the first study (20) no buildup or dissemination of the staphylococci among subjects and their environment was observed. In the second study (21) however, transfer of the organism occurred between environment and one of the subjects without any buildup of the staphylococci.

This report describes the results obtained from a 6-week experiment during which time 4 human male subjects were confined in a Life Support Systems Evalvator under simulated aerospace and controlled metabolic conditions. The subjects were exposed to an increased environmental temperature for part of the time. The results of the basic nutritional program are reported elsewhere (25). In these studies, selected body areas and the environment were sampled by means of dry cotton swabs which were applied to appropriate culture media. Staphylococci or micrococci were isolated from the culture media and tested for their characteristic biochemical reactions. The bacterial and fungal flora excluding the Micrococcaceae were investigated as part of the overall program (26).

\section{SECTION II}

\section{EXPERIMENTAL METHODS AND PROCEDURES}

Four healthy male subjects were confined in the controlled activity facility $(C A F)^{*}$ for a period of one week, transferred to the Life Support Systems Evaluator (LSSE)* for 34 days, then returned to the CAF for 3 days. The experimental design is shown in table 1 . Throughout the experiment all contacts with the subjects

* The controlled activity facility (CAF) and the Life Support Systems Evaluator (LSSE) at the Aerospace Medical Research Laboratories, Wright-Patterson Air Force Base, Ohio, were used to provide a simulated space cabin environment. 
were minimized. Only personnel gowned in sterile surgical clothing were permitted to enter the CAF and only the subjects entered the chamber. In the transfer of subjects to and from the chamber, personnel and subjects wore sterile surgical apparel. Biological samples were collected daily from all subjects for microbiological, chemical, and physiological tests. Included in the daily schedule were psychological tests, exercise, and free activity periods (table II).

A one-day cycle diet of fresh foods was served throughout the experiment (25).

The cabin temperature was maintained at $73 \pm 4^{\circ} \mathrm{F}$ for weeks 1, 2, 4, and 6 ; it was elevated to $90 \pm 4^{\circ} \mathrm{F}$ during weeks 3 and 5 .

The CAF and chamber were disinfected by sponging and spraying with benzalkonium chloride (BAC) solution. Subjects were thoroughly cleansed before entering either the CAF or chamber; sterile washcloths, towels, and pHisoHexwere used to cleanse all parts of the body. The ears and nose of each subject were cleansed by sterile cotton swabs. No subject was permitted to bathe, shave, groom hair, clean or cut nails, change or remove clothes. Wipes were used only for personal hygiene.

Oral hygiene consisted of an edible dentifrice suppled by the School of Aerospace Medicine, Brooks Air Force Base, Texas, and alternate use of two nylon toothbrushes.

Sweat tests were performed twice a week during the first and second weeks of the chamber period (25).

Body areas sampled were divided into primary regions designated areas " $A$ ", and secondary regions designated areas "B". Areas "A" included ear, nose, throat, gingiva, axilla, groin, glans penis, anus, and toes, and were samples 12 times. Areas "B" included the scalp, eye, ear, arm, umbilicus, and the area under the chest electrode, and were sampled 3 times.

Samples of areas " $A$ " and "B" were taken with sterile dry cotton swabs which were streaked on $5 \%$ sheep blood agar (Baltimore Biological Laboratories - BBL) and then incubated aerobically at $37^{\circ} \mathrm{C}$ for 24 hours, followed by incubation at $30^{\circ} \mathrm{C}$ for 48 hours. The latter incubation enhanced colonial morphology and pigmentation. Fecal plates were obtained for Republic Aviation Corporation. One loop of fecal material was inoculated into Gall's broth and a dilution series was prepared. Onetenth of a milliliter of the $10^{-5}$ and $10^{-6}$ dilution was plated on $10 \%$ sheep blood agar (BBL) and incubated aerobically at $37^{\circ} \mathrm{C}$ for 24 hours. Environmental areas were sampled by exposing $10 \%$ sheep blood agar plates to the air of each environment for one-half hour. 


\section{TABLE I}

\section{EXPERIMENTAL DESIGN}

\begin{tabular}{|c|c|c|c|c|c|c|c|c|}
\hline \multirow[b]{2}{*}{$\begin{array}{l}\text { Test } \\
\text { days }\end{array}$} & \multirow[b]{2}{*}{ Location } & \multirow[b]{2}{*}{$\begin{array}{c}\text { Metabolic } \\
\text { diet }\end{array}$} & \multirow[b]{2}{*}{$\begin{array}{c}\text { Temper- } \\
\text { ature } \\
{ }^{\circ} \mathrm{F}\end{array}$} & \multirow[b]{2}{*}{$\begin{array}{c}\text { Sweat } \\
\text { test }\end{array}$} & \multicolumn{4}{|c|}{ Microbiological sampling } \\
\hline & & & & & $\begin{array}{c}\text { Body } \\
\text { areas } \\
\text { "A" }\end{array}$ & $\begin{array}{c}\text { Body } \\
\text { areas } \\
\text { "B" }\end{array}$ & $\begin{array}{c}\text { Environ- } \\
\text { ment }\end{array}$ & Feces \\
\hline 4 & CAF & Fresh food & $73 \pm 4$ & & $x$ & & $x$ & $x$ \\
\hline 7 & Chamber & Fresh food & $73 \pm 4$ & $x$ & $x$ & $x$ & $x$ & $x$ \\
\hline 7 & Chamber & Fresh food & $90 \pm 4$ & $x$ & $x$ & & $x$ & $x$ \\
\hline 7 & Chamber & Fresh food & $73 \pm 4$ & & $x$ & & $x$ & $x$ \\
\hline 7 & Chamber & Fresh food & $90 \pm 4$ & & $x$ & $x$ & $x$ & $x$ \\
\hline 7 & Chamber & Fresh food & $73 \pm 4$ & & $x$ & & $x$ & $x$ \\
\hline 3 & CAF & Fresh food & $73 \pm 4$ & & $x$ & $x$ & $x$ & $x$ \\
\hline
\end{tabular}


TABLE II

DAILY ACTIVITY SCHEDULE

\begin{tabular}{|c|c|c|c|}
\hline Time & $\frac{\text { Subject No. }}{33}$ & $\frac{\text { Subject No. }}{35}$ & Time \\
\hline $\begin{array}{l}0700 \\
0800\end{array}$ & \multicolumn{2}{|c|}{$\begin{array}{l}\text { Wake; void; physiological meosurements. Transfer food and other items } \\
\text { into chamber. Biological specimens collected and returned to laboratory. }\end{array}$} & $\begin{array}{l}0700 \\
0800\end{array}$ \\
\hline 0900 & Mool A & Meal D & 0900 \\
\hline 0930 & & Sweat test & 0930 \\
\hline 1045 & Physiological measurements & Physiological measurements & 1045 \\
\hline 100 & & Sleep & 1100 \\
\hline 1200 & & & 1200 \\
\hline 1300 & Moal B & & 1300 \\
\hline 1400 & Sweat test & & 1400 \\
\hline 1500 & & & 1500 \\
\hline 1600 & & & 1600 \\
\hline 1700 & Moal C & & 1700 \\
\hline 1800 & & & 1800 \\
\hline 1900 & Physiological meosurements & BMR, Physiologicol measurements & 1900 \\
\hline 2000 & & & 2000 \\
\hline 2100 & Meal D & Moal A & 2100 \\
\hline 2130 & & & 2130 \\
\hline 2200 & & & 2200 \\
\hline 2230 & Physiological measurements & Physiological measurements & 2230 \\
\hline 2300 & Sleep & & 2300 \\
\hline 2400 & & & 2400 \\
\hline 0100 & & Meal B & 0100 \\
\hline 0200 & & & 0200 \\
\hline 0300 & & & 0300 \\
\hline 0400 & & & 0400 \\
\hline 0500 & & Moal C & 0500 \\
\hline 0600 & & & 0600 \\
\hline 0700 & & & 0700 \\
\hline
\end{tabular}


The indirect mutant selection technique of Lederberg and Lederberg (27) was utilized to simplify the biochemical study. Replicators slightly smaller than the standard $100 \times 15 \mathrm{~mm}$ petri dish were cast from aluminum alloy stock and covered with velveteen. The velveteen replicator was pressed against 10 colonies grown on blood agar plates and then applied to the test medium surface.

The bacterial colonies on the initial $5 \%$ sheep blood agar plates were thoroughly examined for colonial morphology, pigmentation, and hemolysis. One of each colonial type observed was streaked on a plate of Trypticase Soy Broth (B. B.L.) plus 1.5\% agar (Difco). Three percent $\mathrm{H}_{2} \mathrm{O}_{2}$ was applied to colonies of gram-positive cocci to detect catalase production and catalase-positive cocci were further tested for several biochemical reactions as shown below.

All cultures considered gram-positive cocci after microscopic observations and found to be catalase-positive were accepted for further biochemical studies. Before replication to biochemical test media, staphylococci were grown on $5 \%$ sheep blood agar plates and theri colonies showed hemolysis after 48 hours of aerobic incubation at $37^{\circ} \mathrm{C}$. Coagulase production and mannitol utilization were observed on the coagulase-mannitol plate medium of Esber and Faulconer (28), to which 15\% sterile coagulase horse plasma (B.B.L.) (29) had been added. Deoxyribonuclease production was detected on DNAase Test Medium (B.B.L.) (30) and gelatinase production on Chapman-Stone Medium (B.B.L.) plates (31). Lotter and Horstman (32) found that results of the coagulase plate method (28) are unreliable after all coagulase-positive cultures had been tested by the coagulase tube method (33).

The test for free coagulase (33) was performed by combining aseptically $0.05 \mathrm{ml}$ of a 24-hour TSB culture with $0.5 \mathrm{ml}$ of 1.5 dilution of citrated horse plasma (B.B.L.) in a sterile $12 \times 75 \mathrm{~mm}$ serological test tube. The plasma was diluted with sterile distilled water. The tubes were incubated in a $37^{\circ} \mathrm{C}$ water bath. Clots formed usually within 3 hours but occasionally were delayed until 18 hours. The method of Blair and Williams (34) was employed for phage typing coagulase-positive isolates. These isolates as well as host strains were grown in TSB for 6 hours at $37^{\circ} \mathrm{C}$. Phage routine test dilutions were applied to the bacteria coated surface of TSA plates by sterile $2.5 \mathrm{cc}$ disposal syringes.

The Communicable Disease Center, Atlanta, Georgia, supplied 22 strains of $S$. aureus from the International set for phage typing. These control cultures included strains $3 a, 3 b, 3 c, 6,7,29,42 d, 42 e, 47,52,52 a, 53,54,55,71,75,77,79$, $80,81,83 a$, and 187 . Strain UC-18 was supplied by Dr. E. O. Hill, Surgical Bacteriology Department, Cincinnati General Gospital, Cincinnati, Ohio. Micrococcus roseus strain 516 and Sarcina lutea strain 533 were obtained from the American Type Culfure Collection. These cultures were tested for production of hemolysis, coagulase, deoxyribonuclease, gelatinase, and mannitol utilization. The staphylococci were positive for each marker, al though $M$. roseus and $S$. lutea were uniformly negative. 
All control cultures were maintained on Brain-Heart Infusion (Difco) plus $1.5 \%$ agar slants and transferred every 2 months.

Statistical tests included analysis of variance, $x^{2}$, and Student's $t$-test. The factors of body areas " $A$ ": subjects, time, body areas, and interaction were tested by analysis of variance at the 0.01 level of significance (35). In each case, the first and last halves of the sampling periods were summed. Thus 2 measures for each subject and body area were obtained. To simplify statistical handling of the data for the analysis among subjects as a function of time and test conditions, the staphylococci were grouped into 3 catagories on the basis of biochemical reactions: $C M$-isolates produced coagulase and utilized mannitol; D-isolates produced deoxyribonuclease; $X$-isolates were positive for all except $C M$ and $Y$-isolates were positive for all except $D$. A separate analysis was run on the $C M$ frequencies, another on the $D$, another on the $X$ (all biochemical types positive except for $C M$ ) and another on the $Y$ (all biochemical types positive except for $D$ ). The factors in body area "A" were tested as follows: a test was carried out on the 4 subjects to determine if a significant difference existed among subjects. The test for time was made to determine if a significant difference in frequency of biochemical types occurred between the 2 time periods. The test for body areas was made to determine if one or more of the body areas had a significantly higher frequency than the other body areas considered. The test for interaction was made to determine the effect when 2 or more factors change at the same time. Two types of interaction considered were subject versus time and body area versus time. For example, let us examine subject versus time interaction. If both subjects $A$ and $B$ possess a higher number of types by the same relative amount, no interaction can be concluded. If subject $A$ were higher and subject $B$ were lower, however (for the second time period) then a significant interaction would probably exist. In the case of body areas "B", subjects and body areas were analyzed by a $X^{2}$ test at the 0.01 level of significance (36). The CM, $D, X$, and $Y$ frequencies were summed for each body area and subject. Time and location in the prechamber, chamber, and postchamber periods of the environment were analyzed by Student's t-test (36). This test was applied to the proportion of frequencies observed to the total possible for $C M, D, X$, and $Y$. An 0.01 level of significance was selected. The first and last halves of the sampling periods in the chamber were compared. Chamber results were matched with prechamber and postcha mber results. 


\section{SECTION III}

\section{RESULTS}

The data obtained in this experiment are shown in tables III through V. Table III demonstrates the biochemical types recovered from selected environmental areas. Areas sampled included bed, dining table, work table, and personal hygiene area floor for prechamber and postchamber sampling days in the CAF. While the subjects were confined to the LSSE, the bed, fore table, aft table, and personal hygiene area floor were sampled. Potentially pathogenic staphylococci were detected by one or more of the following indices: $C=$ coagulase production; $M=$ mannitol utilization; $D=D N A a s e$ production; $G=$ gelatinase production; and $H=$ hemolysis on $5 \%$ sheep blood agar. The $(x)$ in the table indicates the occurrence of a particular biochemical type no matter how many times it was isolated. Table IV shows the biochemical types recovered from selected body areas "A" of test subjects which were ear, nose, throat, gingiva, axilla, groin, glans penis, anus, and toes. Body areas "B" of test subjects included in table $V$ were scalp, eye, area under chest electrode, forearm, and umbilicus.

The number of catalase-positive cocci, presumably staphylococci, totaled 1043 cultures.

Table VI summarizes the results of the statistical analysis of the biochemical types recovered from the environment and selected body areas of test subjects. The frequency of biochemical types from the body areas "A", body areas "B", and environment was analyzed, respectively, by analysis of variance, $x^{2}$, and Student's t-test. The data show that under body areas " $A$ " the body area factor was significant for $C M, D, X$, and $Y$ types. This means that in one or more body areas there occurred considerably larger frequencies of biochemical types than in other body areas (table VIII). Time was not a significant factor; the frequency of occurrence of $C M, D, X$, and $Y$ types in the first 6 sampling periods did not differ markedly from the frequency of occurrence in the second 6 sampling periods. There was no buildup of any biochemical type as the experiment progressed. No significant difference was observed when the frequency of biochemical types was compared among subjects. The results indicate that the change in frequency among biochemical types from time period 1 (first 6 sampling periods) to time period 2 (second 6 sampling periods) was relatively the same for all body areas and all 4 subjects. Body areas " $B$ " show that comparable frequencies of biochemical types were isolated from all body areas and subjects. There occurred no buildup of $C M, D, X$, and $Y$ types with time. The analysis of the environment was accomplished by making 7 separate statistical tests. $C M, D, X$, and $Y$ biochemical types did not occur more frequently in the prechamber, chamber, and postchamber periods, when the first 6 sampling periods were compared to the second 6 sampling periods, nor in the prechamber, chamber, and postchamber physical areas. There was no apparent buildup of biochemical types in the environment as the experiment proceeded with time. The coagulase reaction on the 
coagulase-mannitol plate medium of Esber and Faulconer (28) produced false positive results. This was shown to be the case when all the coagulase-positive cultures (plate method) were tested by the tube method of Fisk (33). Statistical analysis was carried out on $C$ types as determined by the tube method (33) and by the plate method (28). The results of this analysis appear in table VII which indicates statistical agreement between both methods in the frequency of occurrence of $C$ types under body areas " $A$ ". Analysis on tube coagulase-positive types from body areas " $B$ " and environment could not be accomplished because of a limited amount of data.

Table VII shows the distribution of the frequencies of biochemical types recovered from particular body areas designated as significant body areas "A" in table VI. Underlined number refer to those types found to be significantly higher when their averages were compared by the Duncan Multiple Range Test (35). The nose, groin, glans penis, and anus exhibited the largest frequency of $C M$ types as determined by the plate method of Esber and Faulconer (28); the nose, the largest frequency of $C$ types as determined by the tube method of Fisk (33); D types occurred most frequently in the nose, groin, glans penis, anus, and toes. Of all body areas "A" listed, the nose, groin, glans penis, and anus predominate as those areas most likely to harbor potentially pathogenic staphylococci.

Phage typing of coagulase-positive isolates by the tube method (33) was employed to determine which strains of staphylococci were identical and if exchange of strains occurred between subjects and their environment. Figure I shows on which sampling days phage types were recovered from various body areas of test subjects. It may be observed that phage type 29 was first isolated from the eye of subject 35 on the third sampling day and then passed to his nose. After having persisted there for 3 consecutive periods, phage type 29 presumably entered the body of subject 35 , as the type was isolated from his feces on the tenth sampling day. Subject 35 probably transferred phage type 29 from his nose to the noses of subjects 33 and 34 as can be noted on the seventh sampling day. Then after remaining shortly on the nose of subject 33, phage type 29 passed to his throat and was recovered from there on the tenth and twelfth sampling days. Rather than having passed from the throat to the nose again of subject 33 , phage type 29 probably remained on his nose but went undetected on the ninth, tenth, and eleventh sampling days. Phage type $6 / 7 / 53 / 83$ a was isolated from the feces of subject 36 in the middle of the sampling period and mutated to phage type 6 as may be noted near the end of the sampling period. Phage type 29 may have been transferred from the nose of subject 35 to the environment around the fifth sampling day. During the period from the sixth to the eleventh sampling day phage type 29 was recovered consistently from the bed, fore table, aft table, and personal hygiene area floor of the chamber. 


\section{DISCUSSION}

Four human male subjects were confined for a 6-week experimental period during which part of the time they were exposed to an increase in environmental temperature. For 28 days the subjects lived in a simulated space environment as provided by the LSSE and part of th is time the subjects wore the MA- 10 space suit, unpressurized. It is tacitly assumed that a certain degree of stress is induced by confinement; in general, by confinement in the space chamber, by the increase in temperature, and by the overall restrictive nature of the 6-week experimental protocol. Under the particular set of circumstances, there were no changes found in biochemical, physiological, or nutritional parameters as evaluated among the subjects (25). The data obtained in the basic nutritional study are in accord with the results obtained in the microbiological study; namely, that confinement even under minimal hygiene conditions did not cause any buildup of potentially pathogenic organisms nor did it cause lowered resistance to infection. The same results were obtained by Lotter, et al. in studies of subjects during confinement in a simulated space chamber $(20,21)$.

These results agree with those of Sladen (37) who studied the effect of isolation of humans upon their bacterial flora. He found that during prolonged contact the subjects retained rather than exchanged phage types; after 12 months of isolation in the Antarctic, the total carrier rate was lowered because of the decrease in the intermittent and occasional carrier rates. Even the persistent carriers who harbored $S$. aureus for as long as 2 years in the Antarctic never developed an infection. It is apparent that a more definitive measure of stress, especially as related to enhancing susceptibility to infection in human subjects is needed if one is to evaluate conditions related to stressful environment.

In general, staphylococci are dispersed in the environment by air, direct contact, and contaminated objects (38). Several investigators have employed phage typing to study the modes of transmission in staphylococcal infection. While studying staphylococcal infections in newborns, Mortimer, et al. (39) observed that the airborne rate of transmission was $8 \%$, whereas that by direct contact through nurses was $43 \%$. Greendyke, et al. (40) stated that more organisms are released to the environment by fecal rather than nasal carriers. The risk of transmission of staphylococci from carriers may be considerable. In one hospital study, a single carrier infected a new patient every 14 days. If 2 carriers of a particular staphylococcus were present, a new infection occurred about every 10 days; the rate amounted to one every 7 days with 3 or more carriers (4l). In the present study 3 phage types, $29,6 / 7 / 53 / 83 a$, and 6 , were recovered. Phage type 29 was disseminated from the 
nose of subject 35 to the noses of subjects 33 and 34 and to the bed, fore table, aft table, and personal hygiene area floor of the chamber. From the feces of subject 36 was recovered phage type $6 / 7 / 53 / 83 a$ and its mutated form, phage type 6 , but there was no transfer to other subjects or environment. It may be noted that only subject 35 had transmitted a staphylococcus to other subjects and the environment. The finding suggests that nasal carriers of staphylococci should be detected and disinfected before association in a confined group.

In the present study coagulase production as determined by the modified tube method of Fisk (33) was selected as the main index of staphylococcal potential pathogenicity, because Lotter and Horstman found (32) that about one-tenth as many coagulase-positive cultures are defected by the tube method of Fisk (33) as by the plate method of Esber and Faulconer (28). However, the factor(s) in the plate medium responsible for the discrepancy between the two methods have not been identified. 
TABLE III

RECOVERY OF BIOCHEMICAL TYPES FROM SELECTED ENVIRONMENTAL AREAS

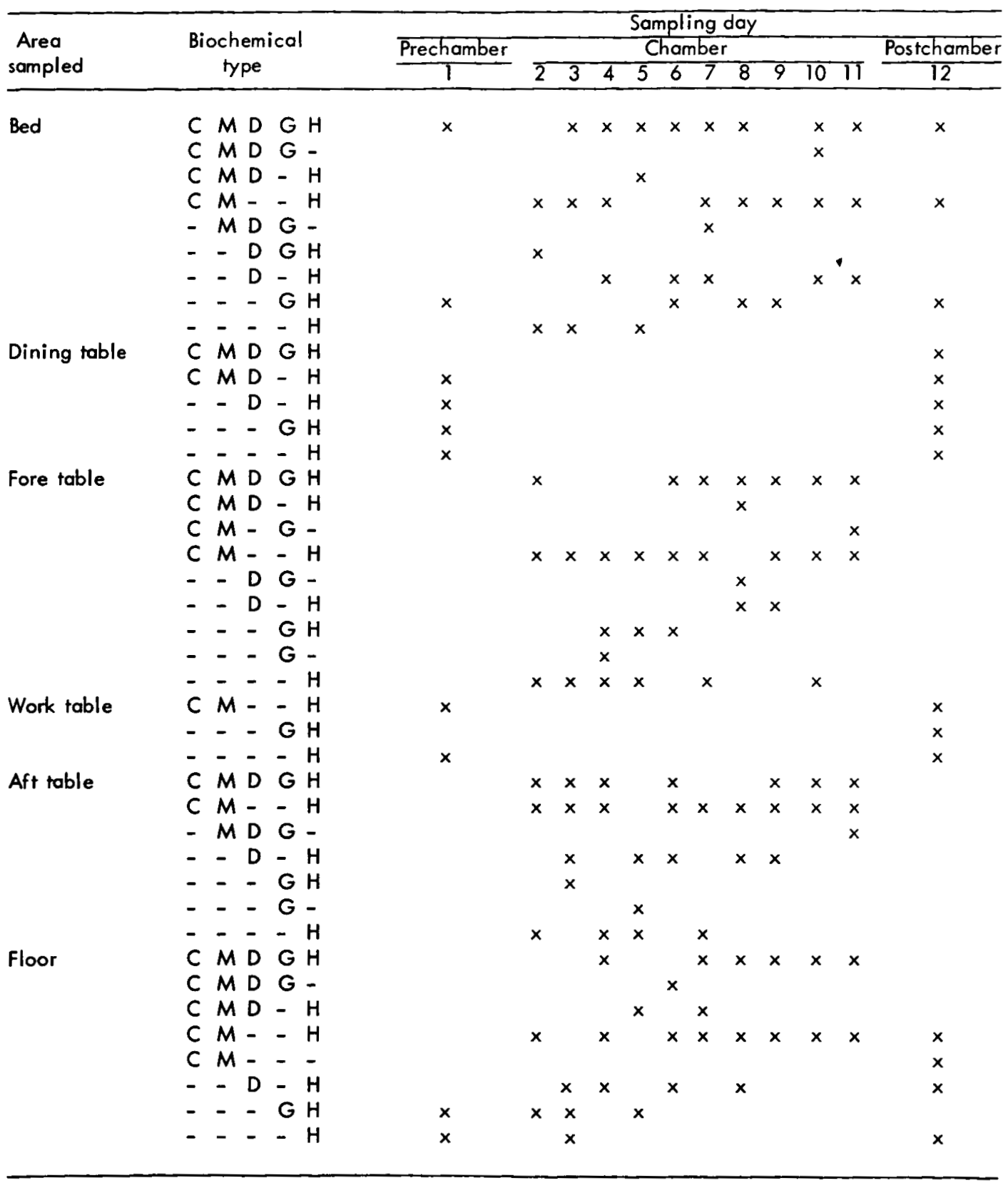

* Biochemical type refers to those cultures with any positive reaction for the series of biochemical criteria used and are coded throughout the tables as follows: $C=$ coagulase production; $M=$ mannitol utilization; $D=$ DNAase production; $G=$ gelatinase production; $H=$ hemolysis on $5 \%$ sheep blood agar. 
TABLE IV

RECOVERY OF BIOCHEMICAL TYPES FROM BODY AREAS "A" OF TEST SUBJECTS

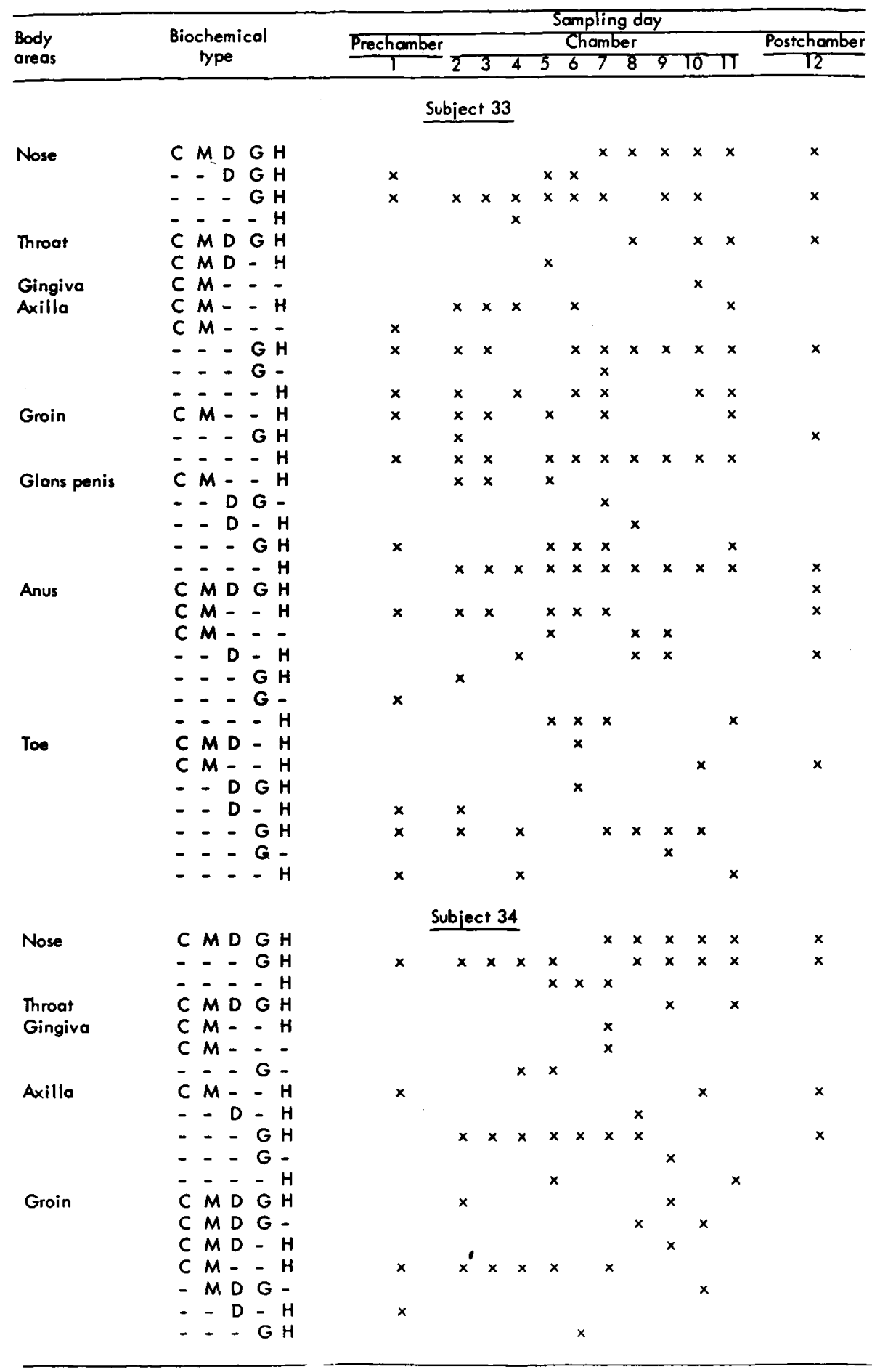


TABLE IV, continued

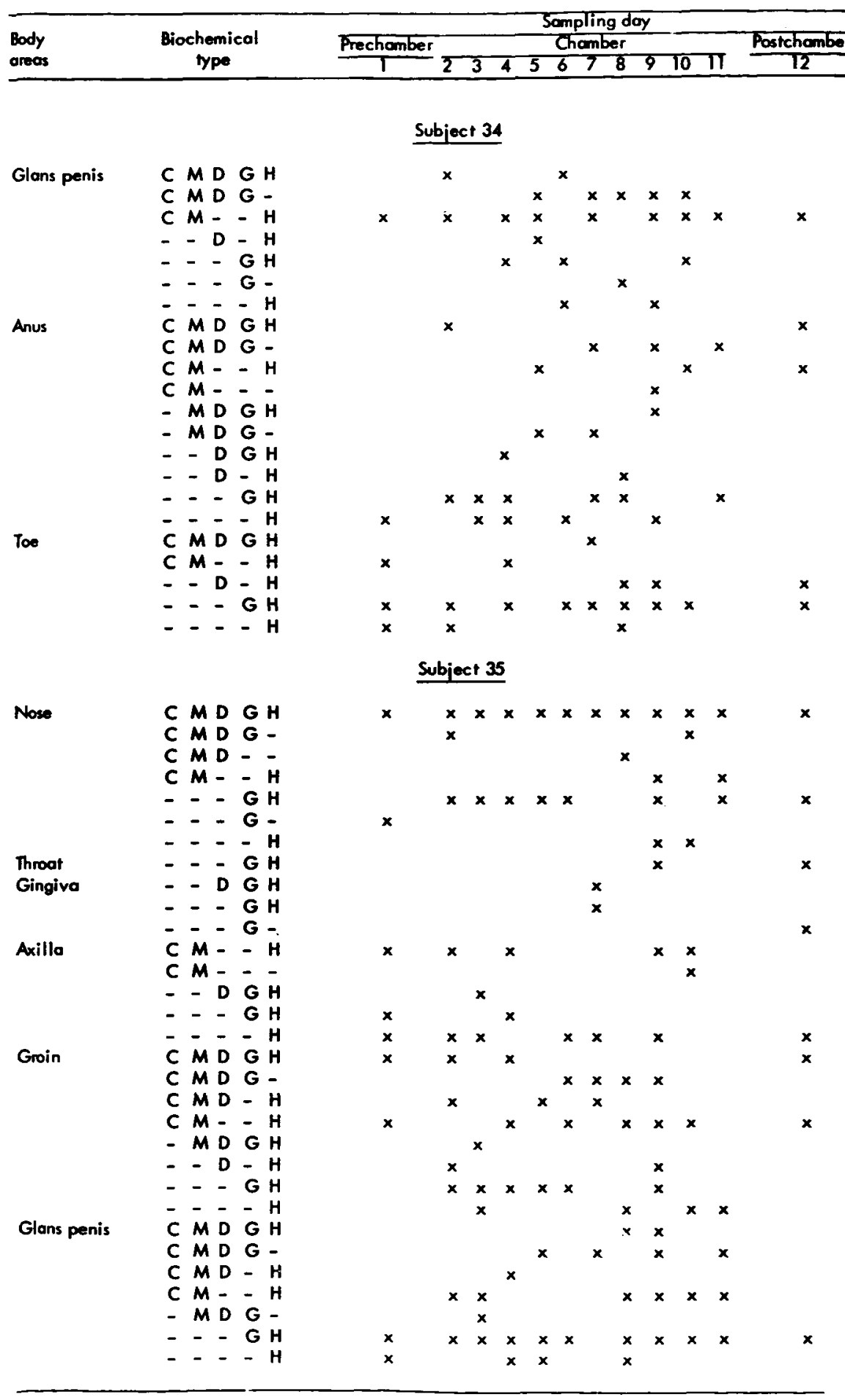


TABLE IV, continued

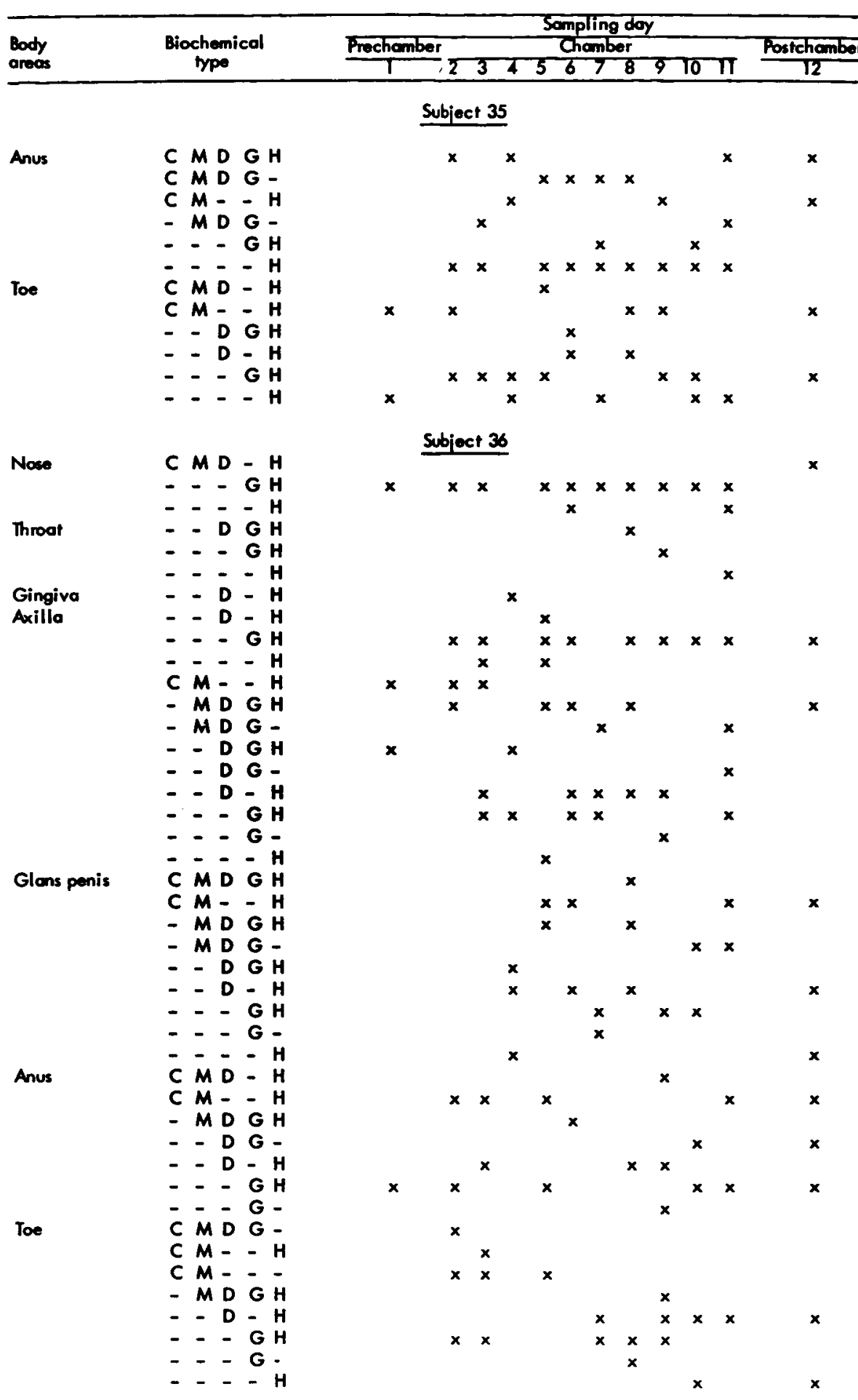


TABLE V

RECOVERY OF BIOCHEMICAL TYPES FROM BODY AREAS "B" OF TEST SUBJECTS

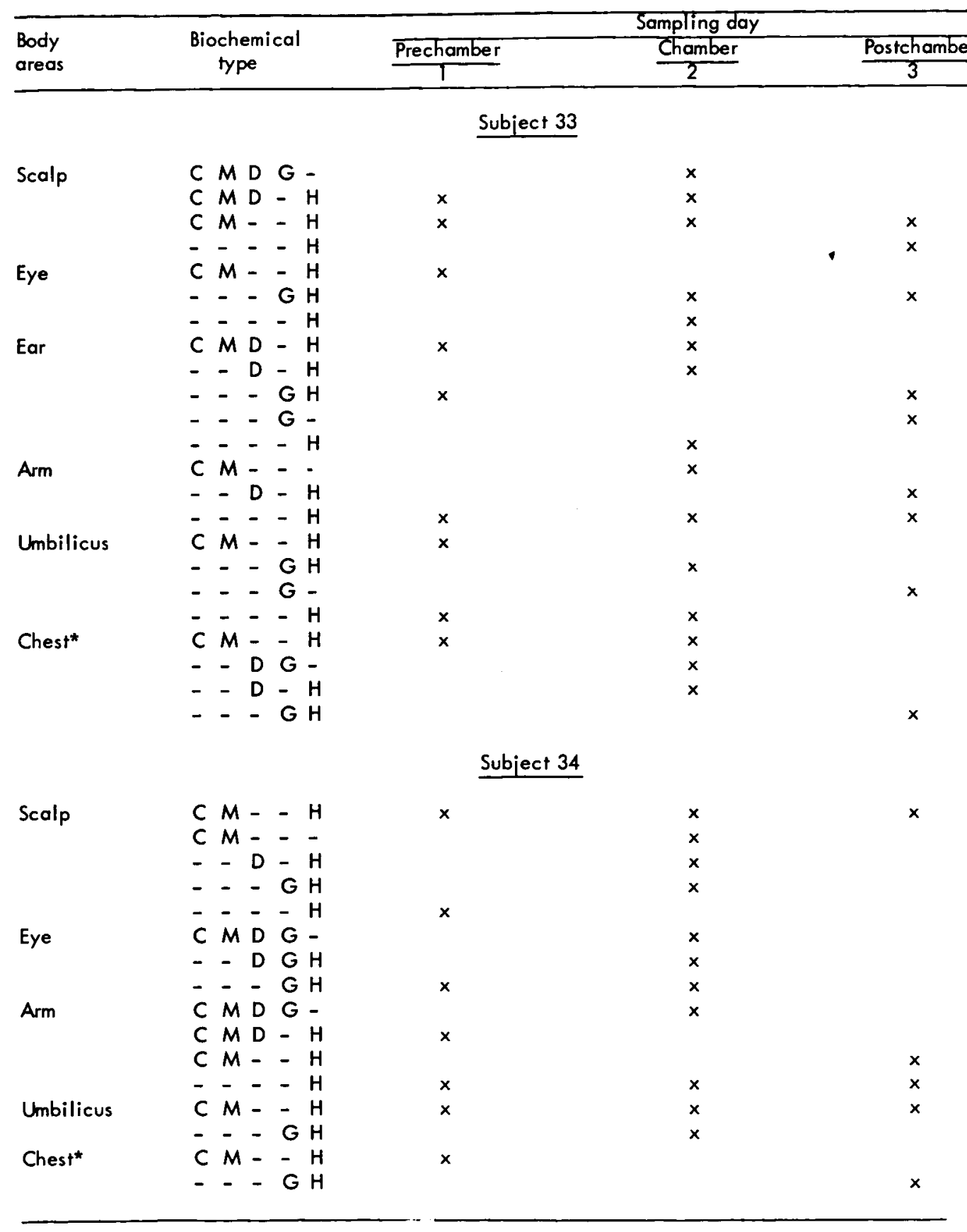

* Area under chest electrode sampled. 
TABLE V, continued

\begin{tabular}{lllll}
\hline $\begin{array}{l}\text { Body } \\
\text { areas }\end{array}$ & $\begin{array}{c}\text { Biochemical } \\
\text { type }\end{array}$ & $\frac{\text { Prechamber }}{1}$ & $\frac{\text { Chamber }}{2}$ & $\frac{\text { Postchamber }}{3}$ \\
\hline
\end{tabular}

\section{Subject 35}

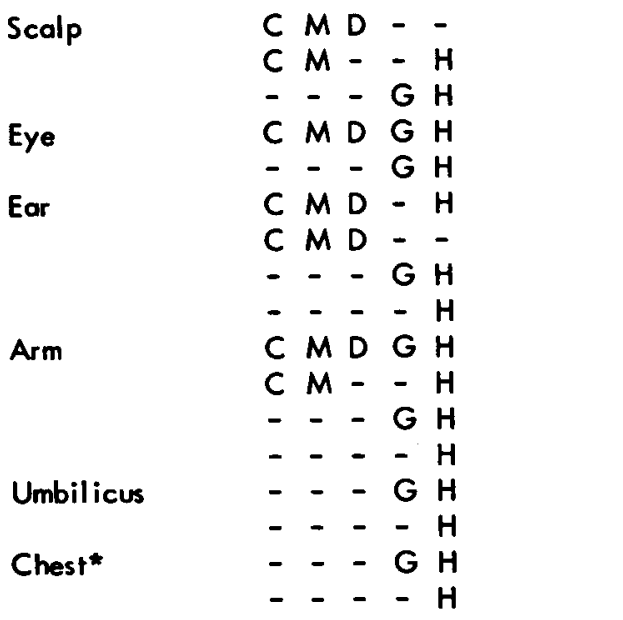

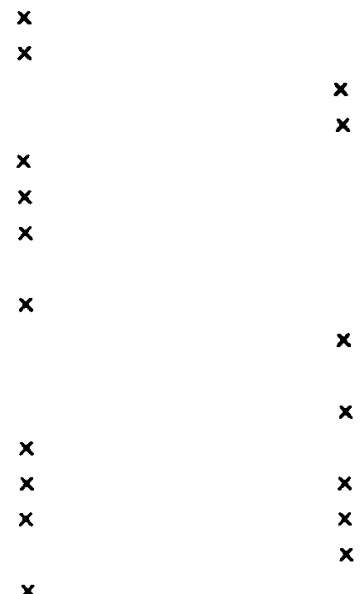

Subject 36

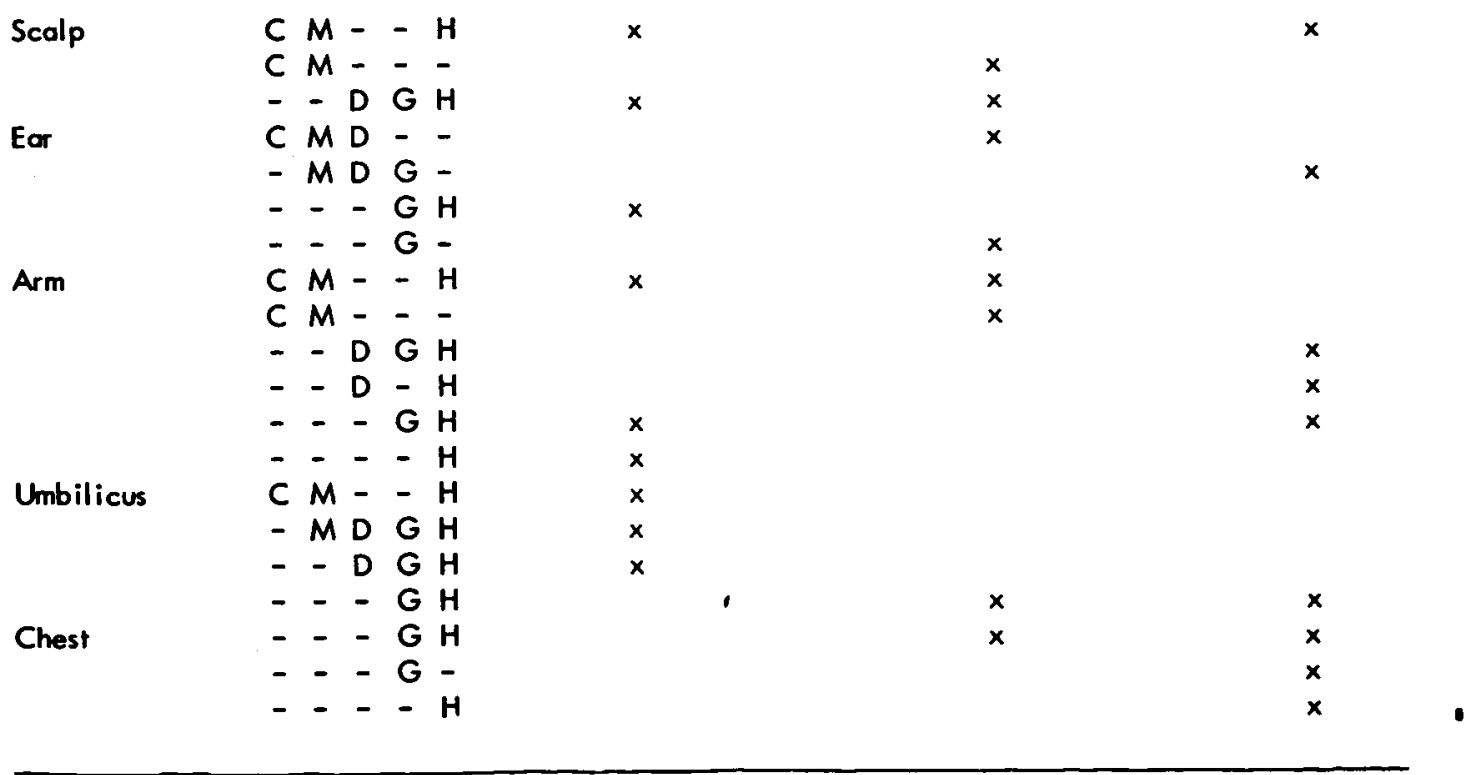


SUMMARY OF STATISTICAL ANALYSIS OF BIOCHEMICAL TYPES RECOVERED FROM SELECTED BODY AREAS OF TEST SUBJECTS AND THE ENVIRONMENT

\begin{tabular}{|c|c|c|c|}
\hline \multirow[b]{2}{*}{ Factors } & \multicolumn{3}{|c|}{ Biochemical types* } \\
\hline & $C, M$ & $\mathrm{D}$ & $X, Y$ \\
\hline \multicolumn{4}{|c|}{ Body areas "A" } \\
\hline Body areas & $S$ & $\mathrm{~S}$ & $\mathrm{~S}$ \\
\hline Subjects & NS & NS & NS \\
\hline Time** & NS & NS & NS \\
\hline Interaction: subject vs. time & NS & NS & NS \\
\hline body area vs. time & NS & NS & NS \\
\hline \multicolumn{4}{|c|}{ Body areas "B" } \\
\hline Body areas & NS & NS & NS \\
\hline \multicolumn{4}{|c|}{ Environment } \\
\hline Prechamber vs. postchamber time & NS & NS & NS \\
\hline Prechamber physical areas & NS & NS & NS \\
\hline Postchamber physical areas & NS & NS & NS \\
\hline Chamber time & NS & NS & NS \\
\hline Chamber physical areas & NS & NS & NS \\
\hline Chamber vs. prechamber time & NS & NS & NS \\
\hline Chamber vs. postchamber time & NS & NS & NS \\
\hline
\end{tabular}

* $X=$ all positives except for $C$ and $M ; Y=$ all positives except for $D ; S=$ significant; NS = not significant .

** Time period 1 compared to time period 2. 
TABLE VII

SUMMARY OF STATISTICAL ANALYSIS OF BIOCHEMICAL TYPE "C" RECOVERED

FROM SELECTED BODY AREAS OF TEST SUBJECTS AND THE ENVIRONMENT

\begin{tabular}{|c|c|c|c|}
\hline Factors & & $C^{*}$ & $C^{* *}$ \\
\hline \multicolumn{4}{|c|}{ Body areas "A" } \\
\hline Body areas & & $S$ & $\mathrm{~s}$ \\
\hline Subjects & & NS & $\mathrm{N}$ \\
\hline Time & & NS & \\
\hline \multirow[t]{2}{*}{ Interaction: } & subject vs. time & NS & \\
\hline & body area vs. time & NS & \\
\hline
\end{tabular}

Body areas "B"

Body areas

NS

Environment

Prechamber vs. postchamber time NS

Prechamber physical areas

NS

Postchamber physical areas

NS

Chamber period

NS

NS

Chamber physical area

NS

Chamber vs. prechamber time

NS

Chamber vs. postchamber time

NS

* Coagulase production determined by modified tube method of Fisk

** Coagulase production determined by coagulase-mannitol plate method of Esber and Faulconer 
TABLE VIII

FREQUENCY OF BIOCHEMICAL TYPES RECOVERED FROM

SIGNIFICANT BODY AREAS

\begin{tabular}{llllllllllll}
\hline $\begin{array}{c}\text { Biochemical } \\
\text { type }\end{array}$ & Nose & Throat & Gingiva & Axilla & Groin & $\begin{array}{c}\text { Glans } \\
\text { penis }\end{array}$ & Anus & Toe & Ratio** \\
\cline { 2 - 9 } C, M & $25^{* *}$ & 7 & 2 & 14 & 28 & 28 & 29 & 15 & 18.50 \\
$\mathrm{D}$ & 28 & 8 & 3 & 5 & 26 & 24 & 27 & 16 & 17.12 \\
$\mathrm{X}$ & 42 & 5 & 13 & 38 & 35 & 38 & 39 & 39 & 31.12 \\
$\mathrm{Y}$ & 43 & 1 & 15 & 41 & 38 & 42 & 40 & 38 & 32.62 \\
\end{tabular}

* Sum of observations for all subjects in all sampling periods.

** Ratio $=\frac{\text { number of types }}{\text { sum of body areas }}$

$\uparrow$ Coagulase production detected by coagulase-mannitol plate method of Esber and Faulconer (28). 


\section{TABLE IX}

RECOVERY OF BIOCHEMICAL TYPES FROM FECES OF TEST SUBJECTS

\begin{tabular}{|c|c|c|c|c|c|c|c|c|c|c|c|c|}
\hline \multirow{4}{*}{$\begin{array}{c}\text { Subject } \\
\text { No. } \\
33\end{array}$} & \multirow{3}{*}{\multicolumn{5}{|c|}{$\begin{array}{c}\text { Biochemical } \\
\text { type }\end{array}$}} & \multicolumn{7}{|c|}{ Sampling day } \\
\hline & & & & & & \multirow{2}{*}{$\frac{\text { Prechamber }}{1}$} & \multicolumn{5}{|c|}{ Chamber } & \multirow{2}{*}{$\frac{\text { Postchamber }}{12}$} \\
\hline & & & & & & & 23456 & 67 & 89 & 10 & 11 & \\
\hline & - & - & - & - & - & & & & & & & \\
\hline 34 & - & - & - & - & - & & & & & & & \\
\hline 35 & $C$ & $M$ & $D$ & $G$ & $\mathrm{H}$ & & & & & $x$ & & \\
\hline 36 & $C$ & $M$ & $D$ & G & H & & & & & $x$ & $x$ & \\
\hline & $\mathrm{C}$ & $M$ & $D$ & - & - & & & $x \times$ & $x$ & & & \\
\hline & - & - & - & $G$ & - & & & & $x$ & & & \\
\hline
\end{tabular}




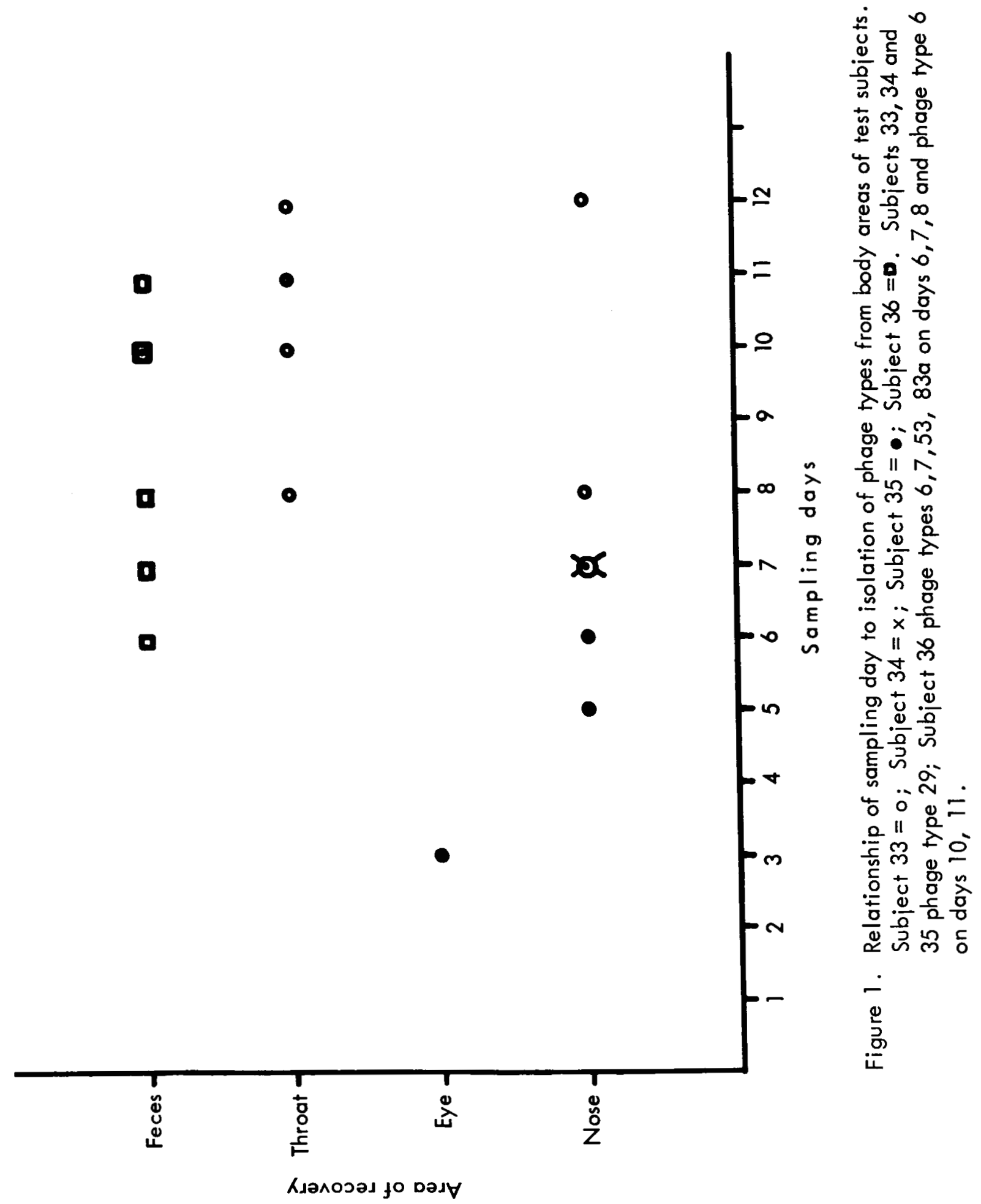




\section{REFERENCES}

1. Henius, K.: "Der einfluss des hungers und von staphylokokkenifektion auf tuberkulose kaninchen. Versuch von schlussfolgerunger auf die menschentuberkulose." Bietr.z. Klin.d. Tuberk., 66: 616-630, 1927.

2. Elek, S.D.: Staphylococcus Pyogenes and Its Relation to Disease. E. and S. Livingstone, Ltd., Edinburgh, 1959, p 150.

3. Dubos, R. J., and Schaedler, R.W.: "Effect of dietary prote ins and amino acids on the susceptibility of mice to bacterial infections." J. Exp. Med., 110: $921-934,1959$.

4. Dubos, R. J., and Schaedler, R. W.: "Effect of nutrition on the resistance of mice to endotoxin and on the bactericidal power of their tissues." J. Exp. Med., 110: 935-950, 1959.

5. Lowbury, E. J. L., Topley, E., and Hood, A. M.: "Chemotherapy for staphylococcus aureus in burns." Lancet, 1: 1036-1042, 1952.

6. Miles, A. A., and Niven, J.S. F.: "Enhancement of infection during shock produced by bacterial toxins and other agents." Brit.J. Exper. Path., 31: 73-95, 1950.

7. Dubos, R. J.: "The evolution of microbial diseases." Bacterial and Mycotic Infections of Man, R. J. Dubos and J. G. Hirsch (ed). J. B. Lippincott Company, Philadelphia, Pennsylvania, 1965, pp 32-34.

8. Fishman, M., and Shechmeister, J. L.: "The effect of ionizing radiation on phagocytosis and the bactericidal power of the blood. II. The effect of radiation on ingestion and digestion of bacteria." J. Exp. Med., 101: 275-290, 1955.

9. Reichlin, S., and Glaser, R. J.: "Thyroid function in experimental streptococcal pneumonia in the rat." J. Exp. Med., 107: 219-236, 1958.

10. Einaudi, M.: "Ricerche sulla localizzazione elettiva dello stafilococco piogeno aureo dopo passaggi in vitro ed in vivo su pelle." Gior. di Batteriol. e Immunol., 10: 957-980, 1933. 
11. Jona, A.: "Le iniezioni di latte e le reasioni immunitarie nell' infezione sperimentale da stafilococco nel coniglio." Gior. di Batteriol. e Immunol., 9: 481-526, 1932.

12. Rosebury, T.: Microorganisms Indigenous to Man. McGraw-Hill Book Company, New York, 1962, pp 14-25.

13. Morse, S. 1.: "Staphylococci and other micrococci." Bacterial and Mycotic Infections of Man, R. J. Dubos and J. G. Hirsch (ed). J. B. Lippincott Company, Philadelphia, Pennsylvania, 1965, pp 412-439.

14. Blair, J.E.: "Factors determining the pathogenicity of staphylococci." Ann. Rev. Microbiol., 12: $491-506,1958$.

15. Blair, J. E.: "What is a staphylococcus?" Bact. Rev., 26:375-381, 1962.

16. Noble, W. C.: "Virulence and the biochemical characters of staphylococci." J. Path. Bact., 91: 181-193, 1966.

17. Panos, C., and $A j l, S . J .:$ "Metabolism of microorganisms as related to the ir pathogenicity." Ann. Rev. Microbiol., 17: 297-328, 1963.

18. Blair, J.E.: "Epidemiological implications of staphylococcal phage typing." Ann. N.Y.Acad. Sci., 65: 152-160, 1956.

19. Blair, J.E., and Carr, M.: "Lysogeny in staphylococci." J. Bact., 82: 984-993, 1961 .

20. Lotter, L. P., Horstman, B. S., and Rack, J. V.: The potential hazard of staphylococci and micrococci to human subjects in a Tife support systems evaluator and on a diet of precooked freeze dehydrated foods. AMRL-TR-67-18, Wright-Patterson Air Force Base, Ohio.

21. Lotter, L. P., Horstman, B. S., and Rack, J. V.: The potential hazard of staphylococci and micrococci to human subjects in a Tife support systems evaluator and on a diet of liquid foods. AMRL-TR-67-21, Wright-Patterson Air Force Base, Ohio.

22. Katchman, B. J., Homer, G. M., Blanchard, W. W., and Dunco, D. P.: Biochemical and physiological evaluation of human subjects in a life support systems evaluator. AMRL-TR-66-159, Wright-Patterson Air Force Base, Ohio, February 1967. 
23. Katchman, B. J., Homer, G. M., Murphy, J. P. F., and Dunco, D. P.: The biochemical, physiological, and metabolic evaluation of human subjects in a life support systems evaluator and on a diet of precooked freeze dehydrated foods. AMRL-TR-67-12, Wright-Patterson Air Force Base, Ohio.

24. Katchman, B. J., Homer, G. M., Murphy, J. P. F., Linder, C. A., and Must, V.R.: The biochemical, physiological, and metabolic evaluation of human subjects in a life support systems evaluator and on a liquid food diet. AMRL-TR-67-72, Wright-Patterson Air Force Base, Ohio.

25. Katchman, B. J., Murphy, J. P. F., Linder, C. A., and Must, V. R .: The effect of cabin temperature on the nutritional, biochemical, and physidlogical parameters of human subjects in a life support systems evaluator. AMRL-TR-67-107, Wright-Patterson Air Force Base, Ohio.

26. Riely, P. E., Geib, D., and Shorenstein, D.: Determination of indigenous microflora of men in controlled environments. AMRL-TR-66-33, WrightPatterson Air Force Base, Ohio, April 1966.

27. Lederberg, J., and Lederberg, E. M.: "Replica plating and indirect selection of bacterial mutants." J.Bact., 63: 399-406, 1952.

28. Esber, R., and Faulconer, R. J.: "A medium for initial visual demonstration of production of coagulase and fermentation of mannitol by pathogenic staphylococci." Am. J.Clin. Path., 32: 192-194, 1959.

29. Vera, H. D., Mangold, C., Zeman, J., and Olitzky, I.: "Coagulase test plates for classification of staphylococci." Public Health Lab., 17(5): 101104, 1959.

30. DiSalvo, J.: "Deoxyribonuclease and coagulase activity of micrococci." Med. Tech. Bull., 9: 191-196, 1958.

31. Chapman, G.H.: "An improved Stone medium for the isolation and testing of food-poisoning staphylococci." Food Res., 13: 100-105, 1948.

32. Lotter, L. P., and Horstman, B. S. M.: "Comparison of a tube method and a plate method for detecting coagulase production." Am. J. Clin. Path., 48: $153-155,1967$.

33. Fisk, A.: "Technique of coagulase test for staphylococci." Brit. J. Exper. Path., 21: $311-314,1940$. 
34. Blair, J.E., and Williams, R. E. O.: "Phage typing of staphylococci." Bull. World Health Organ., 24: 771-784, 1961.

35. Hicks, C.: Fundamental Concepts in the Design of Experiments. Holt, Rinehart, and Winston, New York, 1964, p 165.

36. Winer, B.: Statistical Principles and Experimental Design. McGraw-Hill Book Company, New York, 1962, p 629 and p 28.

37. Sladen, W. J. L.: "Staphylococci in noses and streptococci in throats of men of isolated and semi-isolated Antarctic communities." J. Hyg. Camb., 63: 105-116, 1965.

38. Barrie, D.: "Staphylococcal colonization of the rectum in the newborn." Brit. Med. J., 1: 1574-1576, 1966.

39. Mortimer, E. A., Wolinsky, E., Gonzaga, A. J., and Rammelkamp, C. H.: "Role of airborne transmission in staphylococcal infections." Brit. Med. J., 1: 319-322, 1966.

40. Greendyke, R. M., Constantine, H. P., Magruder, G. B., Dean, D. C., Gardner, J. H., and Morgan, H. R.: "Staphylococci in a medical ward with special reference to fecal carriers." Am. J. Clin. Path., 30: $318-$ 322,1958 .

41. Williams, R.E. O.: "Healthy carriage of staphylococcus aureus: Its prevalence and importance." Bact. Rev., 27: 56-71, 1963. 


\section{DOCUMENT CONTROL DATA - R \& D}

(Security classification of (ttle, body of abstract and indexing annotation must be entered when the overall report is classified)

1. ORIGINA TING ACTIVITY (Comorate outhor)

Miami Valley Hospital - Department of Research

1 Wyoming St.

Dayton, Ohio 45409

3. REPORT TITLE

THE POTENTIAL HAZARD OF STAPHYLOCOCCI AND MICROCOCCI

TO HUMAN SUBJECTS IN A LIFE SUPPORT SYSTEMS EVALUATOR

WITH ELEVATED CABIN TEMPERATURE

4. DESCRIPTIVE NOTES (TYPe of report and incluaive dates)

Final Report, 12 July 1965 - 25 August 1965

5. AU THOR(S) (First name, middlo initial, last name)

Leonard P. Lotter

Bonnie S. Horstman

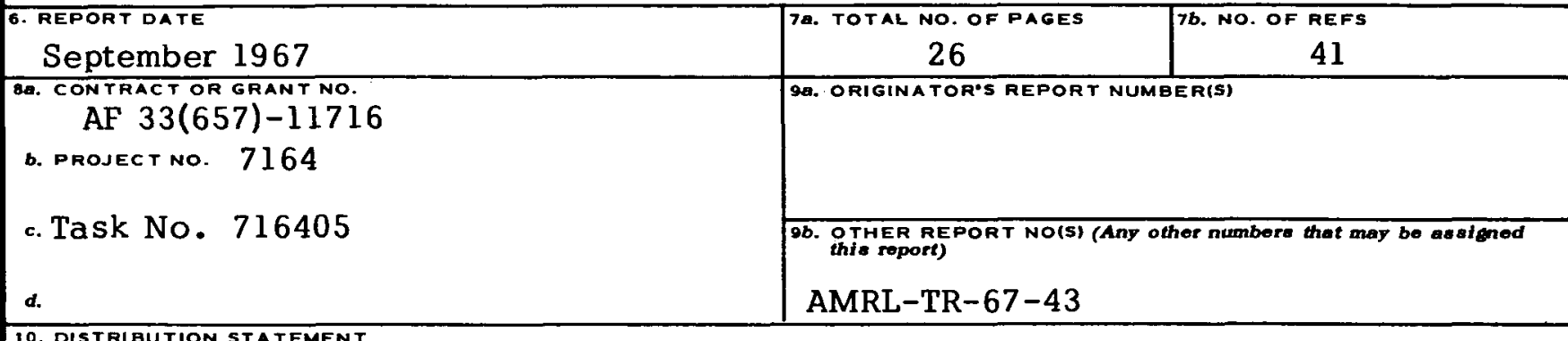

Distribution of this document is unlimited. It may be released to the Clearinghouse, Department of Commerce, for sale to the general public.

11. SUPPLEMENTARY NOTES

Supported in part by NASA Defense Purchase Request $\mathrm{R}-85$.

3. ABSTRACT

Four human male subjects participated in a 6-week simulated aerospace study and were confined under controlled metabolic conditions. During this time 28 consecutive days were spent in a Life Support Systems Evaluator. The subjects ate a diet composed of fresh foods while exposed to simulated aerospace stress of confinement, wearing an unpressurized pressure suit, increased environmental temperature, experimental diet, and minimal personal hygienic conditions. Body and environmental areas were sampled and catalase-positive, gram-positive cocci isolated were tested for production of coagulase, deoxyribonuclease, hemolysin, gelatinase, and utilization of mannitol. The results showed no significant differences in frequency of occurrence of biochemical types among subjects and among environmental areas during the chamber period. There were significant differences in the frequency of occurrence of biochemical types on nose throat, gingiva, axilla, groin, glans penis, anus, and toe. There was no buildup of biochemical types with time in any test condition. Though 3 phage types, 29, 6/7/53/ $83 a$, and 6 , were recovered initially from 2 subjects, only one subject had transmitted astaphylococcus to other subjects and the environment. In the concurrent metabolic studies the physiological, biochemical and nutritional parameters investigated were all in the normal range of clinical values. Confinement under simulated aerospace conditions for at least 28 consecutive days and conditions of minimal personal hygiene show that no unique set of circumstances are operable that would require the establishment of special biomedical criteria. 


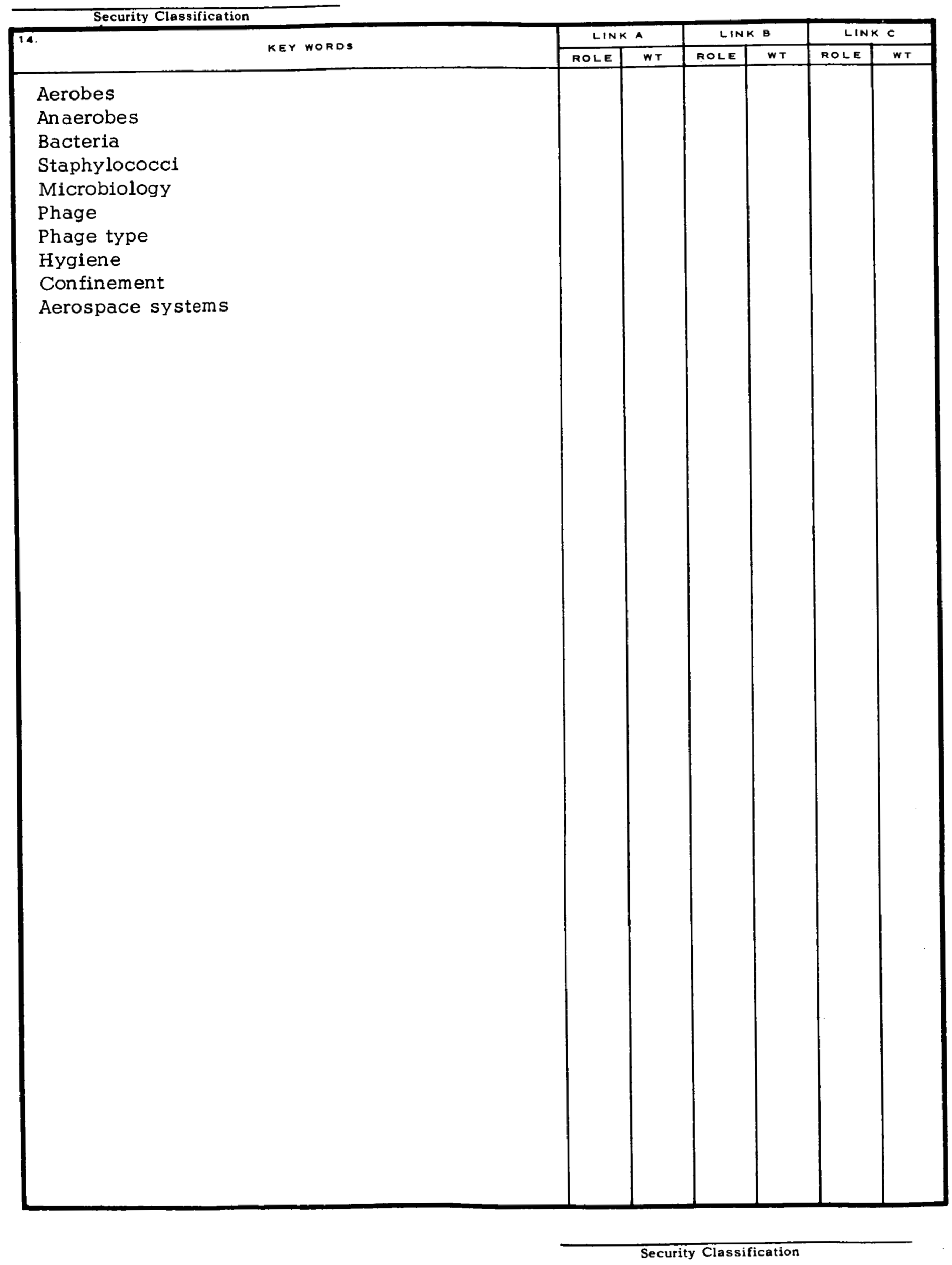

